\title{
HAK ATAS DERAJAT PELAYANAN KESEHATAN YANG OPTIMAL
}

\section{Rif'atul Hidayat}

Akademisi Universitas Islam Indonesia Yogyakarta

Jalan Kaliurang KM. 14.5, Umbulmartani, Ngemplak, Umbulmartani, Ngemplak, Kabupaten Sleman,

Daerah Istimewa Yogyakarta 55584

E-mail: rifatul.hidayat@gmail.com

\section{Pendahuluan}

Di Indonesia hukum memegang peran penting dalam berbagai segi kehidupan bermasyarakat dan bernegara. Salah satunya yaitu di bidang kesehatan, kesehatan merupakan hak asasi manusia dan salah satu unsur kesejahteraan yang harus diwujudkan sesuai dengan cita-cita bangsa Indonesia sebagaimana dimaksud dalam pancasila dan Undang-Undang Dasar Negara Republik Indonesia Tahun 1945.

Membicarakan hak asasi manusia (HAM) berarti membicarakan dimensi kehidupan manusia.

HAM, ada bukan karena diberikan oleh masyarakat dan kebaikan dari Negara, melainkan berdasarkan martabatnya sebagai manusia. Pengakuan atas eksistensi manusia menandakan bahwa manusia sebagai makhluk hidup adalah ciptaan Tuhan Yang Maha Kuasa, Allah SWT patut memperoleh apresiasi secara positif. ${ }^{1}$

Majda El-Muthtaj, Hak Asasi Manusia dalam Konstitusi Indonesia,Cek. 3, Jakarta, Kencana Prenada Media Group, 2009), hlm. 1 
Dalam mewujudkan derajat kesehatan yang optimal bagi setiap orang, yang merupakan bagian dari kesejahteraan, diperlukan dukungan hukum bagi penyelenggaraan di bidang kesehatan. Hak atas derajat kesehatan yang optimal akan semakin kuat klaimnya jika dijustifikasi dengan jalan mengaitkannya dengan hak hidup, berhak atas hidup ekivalen dengan berhak atas derajat kesehatan yang optimal. ${ }^{2}$ Pada mulanya upaya penyelenggaraan kesehatan hanya berupa upaya pengobatan penyakit dan pemulihan kesehatan. Kemudian secara berangsur-angsur berkembang kearah kesatuan pada upaya pembangunan kesehatan yang menyeluruh, terpadu dan berkesinambungan yang mencakup upaya promotif (peningkatan), preventif (pencegahan), kuratif (penyembuhan) dan rehabilitatif (pemulihan).

Upaya penyelenggaraan kesehatan sebagaimana dimaksud di atas, dipengaruhi oleh faktor lingkungan sosial budaya, termasuk ekonomi, lingkungan fisik dan biologis yang bersifat dinamis dan kompleks. Menyadari betapa luasnya hal tersebut, pemerintah melalui sistem kesehatan nasional, berupaya menyelenggarakan kesehatan yang bersifat menyeluruh, terpadu, merata, dan dapat diterima serta terjangkau oleh seluruh lapisan masyarakat luas, guna mencapai derajat kesehatan yang optimal. ${ }^{3}$

Dalam hal program pembanguan nasional di bidang kesehatan yang diupayakan untuk meningkatkan derajat kesehatan melalui pengembangan dan pemantapan semua kebijaksanaan dalam sistem kesehatan nasional yang mencerminkan upaya pemerintah untuk membela hak-hak pasien selaku konsumen dalam pelayanan kesehatan, peningkatan derajat kesehatan merupakan suatu konsekwensi logis terhadap mutu pelayanan kesehatan yang menyeluruh dan terpadu sehingga mutu pelayanan dan penyediaan fasilitas pada setiap rumah sakit harus dirasakan oleh semua pihak dengan perasaan yang lega.

Kemampuan manajemen kesehatan yang merupakan kunci dari keberhasilan pembangunan kesehatan pada saat ini belum sepenuhnya memadai. Beberapa hal yang menjadi faktor

\footnotetext{
2 Titon Slamet Kurnia, Derajat Kesehatan Optimal sebagai HAM di Indonesia, (Bandung, PT. Alumni, 2007), hlm. 46

3 Bahder Johan Nasution, Hukum Kesehatan Pertanggungjawaban Dokter, (Jakarta, PT. Rineke Cipta, 2005), hlm. 2
}

penyebabnya adalah masih belum memadainya sistem informasi kesehatan untuk diserbarluaskan kepada masyarakat, integrasi pelayanan kesehatan yang belum berjalan dengan baik, dan belum mantapnya pengendalian dan pengawasan serta penilaian program yang ditetapkan. Umumnya sorotan tersebut lebih ditujukan pada kekurangan pihak dokter dalam memenuhi hak-hak pasien, pemeriksaan dokter yang tidak tepat waktu, kurangnya informasi medis yang diberikan kepada pasien, prosedur pelayanan yang menyulitkan konsumen (pasien), perlakuan para medis yang diskriminatif antara yang kaya dan yang miskin, pelayanan dokter yang tidak tepat waktu akhirnya terdapat pasien yang meninggal sebelum mendapat pertolongan dan lain-lain.

Pada dasarnya kesalahan atau kelalaian dokter dalam melaksanakan profesi medis, merupakan suatu hal yang penting untuk dibicarakan, hal ini disebabkan karena akibat kesalahan atau kelalaian tersebut mempunyai dampak yang sangat merugikan. Selain merusak atau mengurangi kepercayaan masyarakat terhadap profesi kedokteran juga menimbulkan kerugian pada pasien. ${ }^{4}$ Namun demikian untuk mengetahui seorang dokter melakukan malpratik atau tidak maka dapat dilihat dari unsur standar profesi kedokteran. Standar profesi merupakan batasan kemampuan yang meliputi pengetahuan (knowledge), keterampilan (skill performance) dan sikap profesionalitas (professional attitude) minimal yang harus dikuasai oleh seorang dokter untuk dapat melakukan kegiatan profesionalnya pada masyarakat secara mandiri yang dibuat oleh organisasi profesi. ${ }^{5}$

Uraian diatas tersebut menerangkan, bahwasanya setiap orang mempunyai hak dalam memperoleh pelayanan kesehatan yang aman, bermutu, dan terjaukau. Sesuai dengan pasal 5 ayat (2) UU Nomor 36 Tahun 2009 tentang Kesehatan, yaitu : ${ }^{6}$

\section{"Setiap orang mempunyai hak dalam memperoleh pelayanan kesehatan yang aman, bermutu, dan terjangkau”.}

\footnotetext{
${ }^{4}$ Ibid, hlm. 5.

5 Lihat Penjelasan Pasal 50 Undang-undang RI Nomor 29 Tahun 2004 tentang Praktik Kedokteran.

6 Undang-Undang Republik Indonesia Nomor 36 Tahun 2009 tentang Kesehatan, hlm 6.
} 
Berdasarkan uraian di atas, maka problematika HAM dalam pelayanan kesehatan menjadi menarik untuk dibahas khususnya terkait dengan hak atas derajat pelayanan kesehatan yang optimal sebagai bagian kewajiban pemerintah.

\section{A. Hak Atas Kesehatan}

Sejak kesehatan diakui sebagai sebagai salah satu hak asasi manusia, dalam penerapannya terdapat berbagai pengertian. Hal tersebut tidak terlepas dari pengertian "kesehatan". Kesehatan menurut Undang-Undang Nomor 36 tahun 2009 Tentang Kesehatan adalah keadaan sehat, baik secara fisik, mental, spritual maupun sosial yang memungkinkan setiap prang untuk hidup produktif secara sosial dan ekonomis. ${ }^{7}$

Pengertian yang luas itu berpengaruh bagi pemahaman terhadap kesehatan sebagai hak asasi manusia. Dalam Pasal 4 Undang-undang kesehatan ditegaskan bahwa "Setiap orang berbak atas kesehatan", sedangkan Pasal $28 \mathrm{H}$ Undang-Undang Dasar 1945, menegaskan bahwa "Setiap orang berbak bidup sejabtera labir dan batin, bertempat tinggal, dan mendapatkan lingkungan bidup yang baik. dan sehat serta berbak memperoleh pelayanan kesehatan".

Dalam kepustakaan kesehatan, terdapat berbagai istilah yang digunakan untuk menyebut hak asasi manusia di bidang kesehatan, seperti "hak asasi atas kesehatan" (Human Right to Health), atau "hak atas kesehatan"(Right to Health), atau "hak memperoleh derajat kesehatan yang optimal" (The Right to Attainable Standard To Health). ${ }^{9}$ Hukum berkepentingan bukan pada istilah, melainkan pada makna yang terkandung dalam istilah tersebut. Apalagi setelah UUD 45 memberikan jaminan konstitusional terhadap hak atas kesehatan, mengenali hak tersebut secara benar menjadi sangat penting bagi hukum.

Sejalan dengan perkembangan hak asasi manusia yang dinamis, suatu hak asasi manusia cenderung melahirkan hak-hak baru atau melahirkan pengertian yang baru. Sebagai contoh, hak atas pekerjaan yang semula merupakan spesifikasi dari hak atas kesejahteraan, kemudian melahirkan hak baru yang lebih spesifik yaitu hak mendapatkan

7 Undang-Undang Republik Indonesia Nomor 36 Tahun 2009 tentang Kesehatan, hlm 4.

8 http://www.dpr.go.id/id/uu-dan-ruu/uud45, Akses 17 Desember 2016.

9 Eleanor D. Kinney, "The International Human Right to Health", dalam Indiana Law Review, Vol 34, 1559, hlm upah yang layak. Demikian pula halnya dengan hak atas kesehatan, pada awalnya hanya berkaitan dengan perawatan kesehatan (medical care), tetapi kemudian berkembang meliputi berbagai aspek baik individu maupun kesehatan masyarakat dan lingkungan.

Hak atas kesehatan dalam hubungan dengan kategori hak asasi manusia, sering dimasukkan dalam hak asasi manusia generasi kedua dan hak asasi manusia generasi ketiga. Apabila hak atas kesehatan tersebut dikaitkan dengan "kesehatan individu", dia masuk ke dalam hak-hak ekonomi, sosial dan budaya, tetapi jika terkait dengan "kesehatan masyarakat", dia masuk ke dalam hak atas pembangunan. Menurut Muladi, kategori hak asasi manusia generasi ketiga diberikan kepada hak-hak kolektif atas dasar solidaritas antar umat manusia berlandaskan rasa persaudaraan dan solidaritas yang sangat dibutuhkan. Hak asasi manusia ini mencakup antara lain "the right to development; right to peace; and the right to healthy and balanced environment". ${ }^{10}$

Pemahaman kategori hak asasi manusia tersebut tidak boleh bersifat "fragmented" karena akan menimbulkan stratifikasi kualitas. Padahal maksudnya hanyalah untuk memudahkan identifikasi.Perlakuan terhadap hak asai manusia di samping universal, harus bersifat "indivisible and interdependent". ${ }^{11}$

Jadi hak atas kesehatan sebagai suatu hak asasi manusia adalah suatu pengertian "genus", yang merupakan rangkaian dari sekelompok hak-hak spesifik.

\section{Kesehatan Optimal Sebagai Hak Asasi Manusia}

Kesehatan adalah salah satu kebutuhan dasar manusia.Begitu pentingnya, sehingga sering dikatakan bahwa kesehatan bukan segala-galanya, tetapi tanpa kesehatan segala-galanya tidak bermakna. Setelah lebih dari 71 tahun merdeka, kondisi kesehatan di Indonesia belum menunjukkan kemajuan yang berarti.

Terlepas dari indikator yang digunakan oleh kedua lembaga tersebut, derajat kesehatan telah cukup lama dipahami sebagai salah satu hak asasi manusia yang harus dilindungi dan dipenuhi oleh negara. Di kalangan ahli kesehatan di Indonesia,

\footnotetext{
${ }^{10}$ Muladi, Sumbang Saran Perubahan UUD 1945, Yayasan Habibie Center, 2004, hlm 63

${ }^{11}$ Ibid.
} 
telah berkembang pemikiran untuk memasukkan kesehatan sebagai bagian dari "hak asasi manusia", serta memperoleh jaminan konstitusi. Dengan jaminan konstitusi diharapkan perhatian Negara, dalam hal ini Pemerintah, akan jauh lebih besar terhadap pembangunan bidang kesehatan, sehingga kondisi kesehatan di Indonesia akan membaik. Pemikiran itu terus berkembang dalam berbagai seminar dan diskusi sampai akhirnya pada tingkat regulasi.

Sesungguhnya jaminan konstitusi terhadap hak atas kesehatan telah ada sejak masa Konstitusi Republik Indonesia Serikat (RIS) tahun 1949. Dalam Pasal 40 Konstitusi RIS terdapat ketentuan yang menyatakan, "Penguasa senantiasa berusaha dengan sungub-sunggub memajukan kebersiban umum dan kesehatan rakyat'. ${ }^{12}$ Setelah bentuk negara serikat kembali ke bentuk negara kesatuan dan berlakunya Undang-Undang Dasar Sementara 1950 (UUDS), ketentuan Pasal 40 Konstitusi RIS di adopsi ke dalam Pasal 42 UUDS.

Perserikatan Bangsa-Bangsa (PBB) pada tahun 1948 telah menetapkan Universal Declaration of Human Rights, yang di dalamnya mengatur hak atas kesehatan. Dalam Pasal 25 ayat (1) dinyatakan:

\section{"Setiap orang berhak atas taraf hidup yang menjamin kesehatan dan kesejahteraan untuk dirinya dan keluarganya, termasuk pangan, pakaian, perumahan dan perawatan kesehatan...'}

Sejalan dengan itu, Konstitusi World Health Organization (WHO) 1948 telah menegaskan pula bahwa "memperoleh derajat kesehatan yang setinggi-tingginya adalah suatu hak asasi bagi setiap orang" (the enjoyment of the bighest attainable standard of health is one of the fundamental rights of every buman being). Istilah yang digunakan bukan "buman rights", tetapi "fundamental rights", yang kalau kita terjemahkan langsung ke Bahasa Indonesia menjadi "Hak hak Dasar".

Gagasan hak atas kesehatan sebagai hak asasi manusia terus berkembang baik dalam hukum nasional maupun hukum intenasional. Dalam Pasal 4 Undang-undang Nomor 36 tahun 2009 Tentang Kesehatan dinyatakan, "Setiap orang berhak atas kesehatan". Sementara itu dalam Hukum Internasional telah dikembangkan berbagai instrumen hak asasi manusia, antara lain Kovenan Internasional tentang Hak-hak Ekonomi, Sosial

\footnotetext{
${ }^{12}$ Konstitusi Republik Indonesia Serikat

${ }^{13}$ Terjemahan Penulis.
}

dan Budaya (International Covenant on Economic, Social and Cultural Rights) yang ditetapkan pada tahun 1966. Dalam Pasal 12 ayat (1) Kovenan tersebut dinyatakan bahwa "setiap orang mempunyai bak untuk. menikmati standar tertinggi yang dapat dicapai atas kesehatan fisik dan mental'. ${ }^{14}$

Akhirnya pada tahun 2000, melalui Perubahan Kedua Undang-Undang Dasar 1945, kesehatan ditegaskan sebagai bagian dari hak asasi manusia. Dalam Pasal $28 \mathrm{H}$ ayat (1) dinyatakan, bahwa :

"Setiap orang berhak hidup sejahtera lahir dan batin, bertempat tinggal, dan mendapat lingkungan hidup yang baik dan sehat serta berhak memperoleh pelayanan kesehatan."

Masuknya ketentuan tersebut ke dalam Undang-Undang Dasar 1945, menggambarkan perubahan paradigma yang luar biasa. Kesehatan dipandang tidak lagi sekedar urusan pribadi yang terkait dengan nasib atau karunia Tuhan yang tidak ada hubungannya dengan tanggung jawab negara, melainkan suatu hak hukum (legal rights).

Memuat ketentuan jaminan hak asasi manusia, termasuk hak atas kesehatan, ke dalam UndangUndang Dasar 1945, sebagai sebuah komitmen politik Negara, hal ini mungkin telah menyelesaikan berbagai tuntutan politik dan harapan rakyat, tetapi dari perspektif hukum tata negara, hal tersebut masih mengandung persoalan. Persoalan utama terkait dengan beragamnya batasan atau definisi hak atas kesehatan, padahal batasan tersebut sangat penting bagi kepastian hukum. Tanpa batasan yang jelas, akan sulit menentukan ruang lingkup tanggung jawab negara sebagaimana yang ditegaskan dalam UUD 1945.

\section{Hak Atas Derajat Pelayanan Kesehatan yang Optimal Merupakan Kewajiban Pemerintah}

Landasan utama bahwa perlindungan HAM merupakan kewajiban pemerintah adalah prinsip demokrasi bahwa sesungguhnya pemerintah diberi amanah kekuasaan adalah untuk melindungi hak-hak warga negara. Terlebih lagi dengan konsep negara kesejahteraan (welfare state) sebagai konsep negara modern telah memberikan kekuasaan lebih besar pada pemerintah untuk bertindak. Kekuasaan ini semata-mata adalah untuk memajukan dan mencapai

\footnotetext{
${ }^{14}$ Kovenan tersebut telah diratifikasi dengan Undangundang Nomor 12 Tahun 2005 tentang Pengesahan International covenant on civil and political rights (kovenan internasional tentang hak-hak sipil dan politik).
} 
pemenuhan hak asasi manusia. Pemerintah tidak lagi hanya menjaga agar seseorang tidak melanggar atau dilanggar haknya, namun harus mengupayakan pemenuhan hak-hak tersebut. Demikian pula dengan hak atas kesehatan, merupakan kewajiban pemerintah untuk memenuhinya.

Dalam pasal 9 ayat (1) UU Kesehatan dinyatakan, bahwa "Setiap orang berkewajiban ikut mewujudkan, mempertahankan, dan meningkatkan derajat kesehatan masyarakat yang setinggi-tingginya". Ayat (2) menegaskan, bahwa "Kewajiban sebagaimana dimaksud pada ayat (1), pelaksanaannya meliputi upaya kesehatan perseorangan, upaya kesehatan masyarakat, dan pembangunan berwawasan kesehatan". ${ }^{15}$ Seperti yang dikemukakan, kesehatan sebagai hak asasi manusia tidak terlepas dari ciri-ciri hak asasi manusia, yaitu "hak" dalam arti yang sesungguhnya dan bersifat prima facie. Kalaupun ada kewajiban yang melekat pada hak asasi manusia, hal itu semata-mata sebagai pembatasan agar pelaksanaan hak asasi manusia tersebut tidak melanggar hak asasi orang lain. Apabila ketentuan Pasal 9 Undang-undang tersebut dimaknai demikian, kenapa kewajiban itu tidak hanya ditujukan untuk memelihara kesehatan orang lain, tetapi juga kesehatan perseorangannya ? Untuk menjelaskan hal ini penulis menggunakan contoh seorang perokok. Sangat logis apabila seorang perokok dilarang merokok di tempat umum karena akan mengganggu kesehatan orang lain. Dalam kasus ini melekat kewajiban bagi diri si perokok, namun pada saat dia merokok sendiri atau di tempat yang khusus untuk merokok, larangan tersebut menjadi tidak logis.

Menurut penulis, lebih mudah memahani kewajiban asasi dalam kontek tanggung jawab negara/ pemerintah untuk memenuhi hak asasi manusia. Dalam contoh di atas, perokok yang sakit akibat merokok tidak dapat menuntut haknya kepada pemerintah atas derajat kesehatan yang lebih baik, kecuali yang bersangkutan terlebih dahulu berhenti merokok.

Sungguhpun demikian, suatu kewajiban asasi di samping hak asasi manusia agak sulit diterima jika menggunakan konsep hak asasi manusia menurut pikiran dunia barat, karena kewajiban asasi berasal dari sumber yang berbeda. Ajaran-ajaran agama di dunia telah melahirkan dua preposisi. Pertama, bahwa Tuhan menciptakan alam semesta beserta seluruh isinya, termasuk manusia. Kedua,

\footnotetext{
${ }^{15}$ Undang-Undang Republik Indonesia Nomor 36 Tahun 2009 tentang Kesehatan, hlm 6.
}

manusia sebagai mahluk ciptaan Tuhan wajib mempertanggung jawabkan kepada Tuhan atas semua perbuatan dan tindakannya terhadap sesama manusia. ${ }^{16}$

Kedua preposisi tersebut terdapat dalam atau bersumber langsung dari petunjuk Ilahi, seperti Al-Qur'an, Injil, Zabur, dan Taurat, serta petunjukpetunjuk lain yang disampaikan melalui para Nabi. Dalam Islam, kedua preposisi itu tergambar dalam ketegori buqunqullah dan buqunqul-ibad. Huqunqullah adalah kewajiban-kewajiban manusia terhadap Allah yang diwujudkan dalam berbagai ritual ibadah, sedangkan huquuqul-'ibad (hak asasi manusia) merupakan kewajiban-kewajiban manusia terhadap sesama dan makluk hidup lainnya. ${ }^{17}$ Kewajibankewajiban manusia tersebut dalam kepustakaan disebut sebagai (peri) kemanusiaan (bumanity).

Bagi bangsa Indonesia, kedua preposisi tersebut bukan merupakan sesuatu yang asing, bahkan merupakan bagian integral dari kehidupan bernegara. Dalam Pembukaan UUD 1945, alinea keempat, memuat lima prinsip dasar yang berlaku dalam penyelenggaraan negara, yang dikenal sebagai Pancasila. Sila pertama adalah Ketuhanan Yang Maha Esa, dan Sila kedua adalah kemanusiaan yang adil dan beradab.

Kata kunci dari prinsip-prinsip kemanusiaan tersebut di atas adalah tidak memaksakan kehendak kepada orang lain. What you do not wish to be done to yourself, do not do to others. ${ }^{18}$ Jadi kemanusiaan itu berkaitan dengan hubungan sesama manusia. Hal itu agak berbeda dengan pemikiran dunia timur, yang memandang kemanusiaan tidak hanya terbatas pada interaksi antar sesama manusia, tetapi juga antara manusia dengan mahluk hidup lainnya. Pemahaman itu sejalan dengan pendekatan magisreligius yang memandang interaksi harmonis antar manusia beserta lingkungannya sebagai suatu keseimbangan makro kosmis.

Jika dilihat dari buqunqul-ibad terdapat dua macam hak asasi manusia. Pertama, hak asasi manusia yang keberadaannya dapat diselenggarakan oleh suatu negara. Kedua adalah hak asasi manusia yang keberadaannya tidak secara langung dapat dilaksanakan oleh suatu negara. Hak-hak yang

\footnotetext{
${ }^{16}$ Eleanor D. Kinney, The International Human Rights to Health: What Does This Mean for Our Nation and World, (Indiana Law review, Vol. 34:1457), hlm. 2

${ }^{17}$ Syekh Syaukat Hussain, Hak Asasi Manusia dalam Islam, (Jakarta, Gema Insani Press, 1996), hlm. 54

${ }^{18}$ Ibid.
} 
pertama dapat disebut sebagai hak-hak legal (legal rights), sedangkan yang kedua dapat disebut sebagai hak-hak moral (moral rights). ${ }^{19}$ Pada kedua jenis hak tersebut melekat kewajiban-kewajiban, baik yang bersifat hukum (legal obligation) maupun moral (moral obligation).

Kewajiban Pemerintah untuk memenuhi hak atas kesehatan sebagai hak asasi manusia memiliki landasan yuridis internasional dalam Pasal 2 ayat (1) Konvensi Internasional tentang Hak Ekonomi, Sosial dan Budaya yang ditetapkan oleh Majelis Umum PBB 2200 A (XXI) tanggal 16 Desember 1966. Pasal 28 I ayat (4) UUD 1945 menyatakan bahwa perlindungan, pemajuan, penegakan, dan pemenuhan hak asasi manusia adalah tanggung jawab negara, terutama pemerintah. ${ }^{20}$ Kewajiban pemerintah ini juga ditegaskan dalam Pasal 8 Undang-undang Nomor 39 tahun 1999 tentang Hak Asasi Manusia menyatakan perlindungan, pemajuan, penegakan, dan pemenuhan hak asasi manusia terutama menjadi tanggung jawab Pemerintah. ${ }^{21}$

Dibidang kesehatan, Pasal 14 ayat (1) UU Kesehatan menyatakan bahwa "Pemerintab bertanggung jawab merencanakan, mengatur, menyelenggarakan, membina, dan mengawasi penyelenggaraan upaya kesehatan yang merata dan terjangkau oleh masyarakat". Pasal 15 UU Kesehatan menyatakan bahwa "Pemerintah bertanggung jawab atas ketersediaan lingkungan, tantanan, fasilitas kesehatan baik fisik maupun social bagi masyarakat untuk mencapai derajat kesehatan yang setinggi-tingginya". ${ }^{22}$

Upaya pemenuhan hak atas kesehatan dapat dilakukan dengan berbagai macam cara yang meliputi pencegahan dan penyembuhan. Upaya pencegahan meliputi penciptaan kondisi yang layak bagi kesehatan baik menjamin ketersediaan pangan dan pekerjaan, perumahan yang baik, dan lingkungan yang sehat. Sedangkan upaya penyembuhan dilakukan dengan penyediaan pelayanan kesehatan yang optimal. Pelayanan kesehatan meliputi aspek jaminan sosial atas kesehatan, sarana kesehatan yang memadai, tenaga medis yang berkualitas, dan pembiayaan pelayanan

\footnotetext{
${ }^{19}$ Eleanor D.Kinney, loc, cit.

${ }^{20}$ http://www.dpr.go.id/id/uu-dan-ruu/uud45 di akses 5 Januari 2014, 07.20

${ }^{21}$ Undang-Undang Republik Indonesia Nomor 39 Tahun 1999 tentang Hak Asasi Manusia, hlm 4.

${ }^{22}$ Undang-Undang Republik Indonesia Nomor 36 Tahun 2009 tentang Kesehatan, hlm 7-8.
}

yang terjangkau oleh masyarakat. Pasal 12 ayat (2) Konvensi Internasional Hak Ekonomi, Sosial, dan Budaya menguraikan langkah-langkah yang harus diambil untuk mencapai terwujudnya standar tertinggi dalam mencapai kesehatan fisik dan mental adalah: ${ }^{23}$

a. Ketentuan pengurangan tingkat kelahiran mati anak serta perkembangan anak yang sehat;

b. Peningkatan semua aspek kesehatan lingkungan dan industri;

c. Pencegahan, perawatan dan pengendalian segala penyakit menular endemik, penyakit yang berhubungan dengan pekerjaan dan penyakit lainnya;

d. Penciptaan kondisi-kondisi yang menjamin adanya semua pelayanan dan perhatian medis ketika penyakit timbul.

UU tentang Kesehatan mengatur berbagai macam upaya yang menjadi tanggung jawab pemerintah untuk mewujudkan derajat kesehatan yang optimal. Secara umum, Pasal 47 UU Kesehatan menyatakan bahwa "Upaya kesehatan diselenggarakan dalam bentuk kegiatan dengan pendekatan promotif, preventif, kuratif, dan rehabilitatif yang dilaksanakan secara terpadu, menyelurub, dan berkesinambungan". Dalam pasal 48 ayat (1) menyatakan Penyelenggaraan upaya kesehatan sebagaimana dimaksud dalam Pasal 47 dilaksanakan melalui kegiatan:

a. Pelayanan kesehatan;

b. Pelayanan kesehatan tradisional;

c. Peningkatan kesehatan dan pencegahan penyakit;

d. Penyembuhan penyakit dan pemulihan kesehatan;

e. Kesehatan reproduksi;

f. Keluarga berencana;

g. Kesehatan sekolah;

h. Kesehatan olahraga;

i. Pelayanan kesehatan pada bencana;

j. Pelayanan darah;

k. Kesehatan gigi dan mulut;

1. Penanggulangan gangguan penglihatan dan gangguan pendengaran;

m. Kesehatan matra;

\footnotetext{
${ }^{23}$ International Covenant on Economic, Social and Cultural Rights. Adopted and opened for signature, ratification and accession by General Assembly resolution 2200A (XXI) of 16 December 1966. Hlm. 4
} 
n. Pengamanan dan penggunaan sediaan farmasi dan alat kesehatan;

o. Pengamanan makanan dan minuman;

p. Pengamanan zat adiktif; dan/atau

q. Bedah mayat. ${ }^{24}$

untuk mewujudkan derajat kesehatan yang optimal bagi masyarakat, diselenggarakan upaya kesehatan dengan pendekatan pemeliharaan, peningkatan kesehatan (promotif), pencegahan penyakit (preventif), penyembuhan penyakit (kuratif), dan pemulihan kesehatan (rehabilitasi) yang dilaksanakan secara menyeluruh, terpadu dan berkesinambungan.

\section{Penutup}

Adanya pengakuan baik menurut Hukum Nasional maupun Hukum Internasional terhadap hak atas kesehatan tidak berarti masyarakat mempunyai hak untuk sehat. Siapapun pada dasarnya tidak mampu menjamin suatu kondisi kesehatan tertentu, baik Pemerintah maupun masyarakat. Kondisi kesehatan individu lebih banyak dipengaruhi oleh faktor lingkungan tempat tinggal dan keturunan. Definisi-definisi hak atas kesehatan yang digunakan dalam instumeninstrumen hak asasi manusia seperti yang telah dikemukakan, umumnya mengacu pada "derajat kesehatan tertinggi yang dapat dicapai" (the bighest attainable standard of health) sebagai sasaran hak atas kesehatan. Oleh karena itu substansi hak atas kesehatan sangat relatif, karena derajat tertinggi yang dapat dicapai tersebut dapat bervariasi sesuai waktu dan tempat.

Dengan demikian, hak atas kesehatan mengandung dua aspek. Pertama, aspek kesehatan sebagai hak individu yang melahirkan kewajiban pemerintah untuk memenuhinya. Kedua, aspek kesehatan masyarakat. Kesehatan sebagai hak individu belum mendapat pengakuan secara umum dan masih bersifat "dapat dikurangi" (derogable).

\section{Daftar Pustaka}

\section{Literatur}

El-Muthtaj, Majda. Hak Asasi Manusia dalam Konstitusi Indonesia. Jakarta: Kencana Prenada Media Group, 2009.
Nasution, Bahder Johan. Hukum Kesehatan Pertanggungjawaban Dokter. Jakarta: PT. Rineka Cipta, 2005.

Slamet Kurnia, Titon. Derajat Kesehatan Optimal sebagai HAM di Indonesia. Bandung: PT. Alumni, 2007.

Kinney, Eleanor D., The International Human Rights to Health, Indiana Law Review, Volume 34, 2006.

Syekh Syaukat Hussain, Hak Asasi Manusia dalam Islam. Jakarta: Gema Insani Press, 1996.

Muladi, Sumbang Saran Perubahan UUD 1945. Jakarta: Yayasan Habibie Center, 2004

\section{Dokumen Hukum}

International Covenant on Economic, Social and Cultural Rights. Adopted and opened for signature, ratification and accession by General Assembly resolution 2200A (XXI) of 16 December 1966.

Konstitusi Republik Indonesia Serikat

Republik Indonesia. Undang-Undang Tentang Hak Asasi Manusia. Undang-Undang Nomor 39 Tahun 1999.

Republik Indonesia. Undang-Undang Tentang Kesehatan. Undang-undang Nomor 36 Tahun 2009.

Republik Indonesia. Undang-Undang Tentang Pengesahan International covenant on civil and political rights (kovenan internasional tentang hak-hak sipil dan politik). Undangundang Nomor 12 Tahun 2005.

Republik Indonesia. Undang-Undang Tentang Praktik Kedokteran. Undang-undang Nomor 29 Tahun 2004.

\section{Data Elektronik}

http://www.dpr.go.id/id/uu-dan-ruu/uud45 , Akses 17 Desember 2016

\footnotetext{
${ }^{24}$ Undang-Undang Republik Indonesia Nomor 36 Tahun 2009 tentang Kesehatan, hlm 18-19.
} 